\title{
Oligoetherols and polyurethane foams with carbazole ring
}

\author{
Renata Lubczak*
}

"Rzeszów University of Technology, Department of Organic Chemistry, Al. Powstańców Warszawy 6, 35-959 Rzeszów, Poland; e-mail: rlubczak@prz.edu.pl

(Received: 14 November, 2011; published: 15 August, 2012)

\begin{abstract}
The method of synthesis of oligoetherols with carbazole ring from 9-(2,3epo-xypropyl)carbazole and glycerol and oxiranes like ethylene and propylene oxide is presented. Structure and some physicochemical properties of the products is described. The oligoetherols were demonstrated as good substrates for synthesis of polyurethane foams of enhanced thermal resistance.
\end{abstract}

\section{Introduction}

The polymers with carbazole ring inlcuded have some unique physical properties. They are photo- and electroluminescent materials, liquid crystals, electroconductors, and non-linear optical materials [1-7]. Carbazole decomposes at temperatures higher than $260{ }^{\circ} \mathrm{C}$. High thermal resistance of carbazole [8] allow to anticipate that introducing such a ring into oligoetherols increases thermal resistance of them as well as polymers obtained from oligoetherols. The multifunctional oligo- and polyetherols with carbazole ring were not known until now except some preliminary results from this lab [9-11]. Carbazole is mono-functional compound and this is the reason for limited application of synthesis of oligoetherols by its reaction with oxiranes. Therefore, previous studies were devoted to increase its functionality and solubility of carbazole derivatives in oxiranes [12]. Synthesis of linear oligoetherols by reaction of carbazole with epichlorohydrin resulted in formation of 9-(2,3epoxypropyl)carbazole according to the scheme [9-11]:

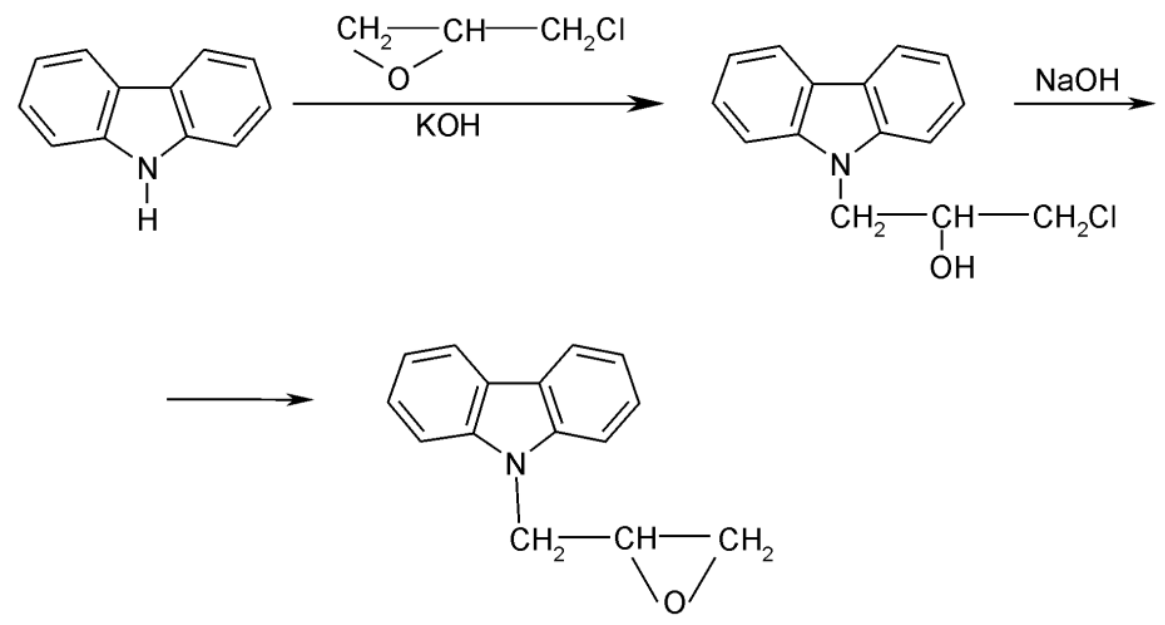

where the epoxide ring was later opened by reaction with water or glycerol. 


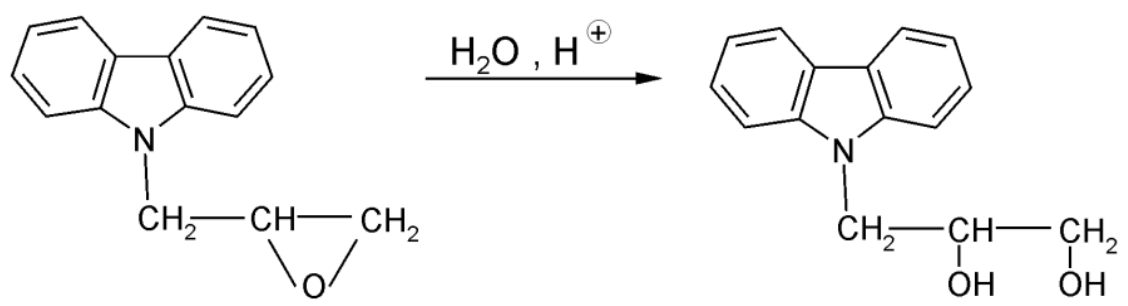

(l)
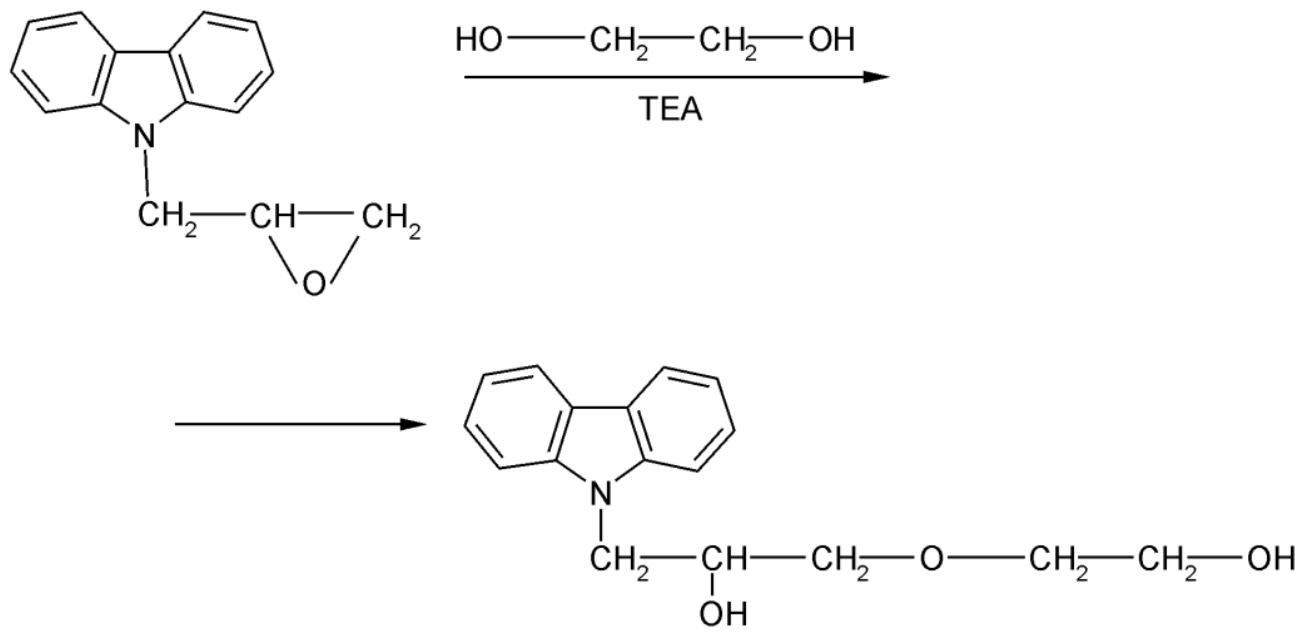

(II)

Obtained products (I) and (II) were then converted into bi-functional oligoetherols by reaction with oxiranes:<smiles>[R]C(C)OC([R])CC([Y])(C)OCC(Cn1c2ccccc2c2ccccc21)OCC([R])OC([Y])(C)C</smiles>

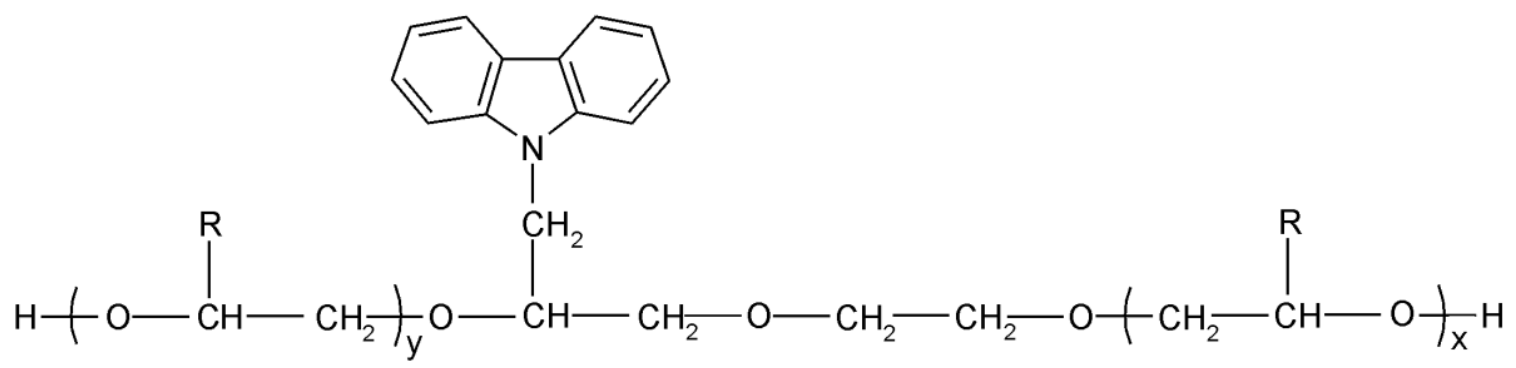

where: $\mathrm{R}=-\mathrm{H},-\mathrm{CH}_{3} ; \quad \mathrm{x}+\mathrm{y}=\mathrm{n}$;

$\mathrm{n}$ - number of molecules of attached oxirane 
Oligoetherols with carbazole ring were also obtained by reaction of carbazole with ethylene chloride and further reaction diethanolamine into diol and its conversion in reaction with excess oxiranes: ethylene and propylene oxides (EO and PO, respectively) [11]:<smiles>ClCCCn1c2ccccc2c2ccc(Cl)cc21</smiles>

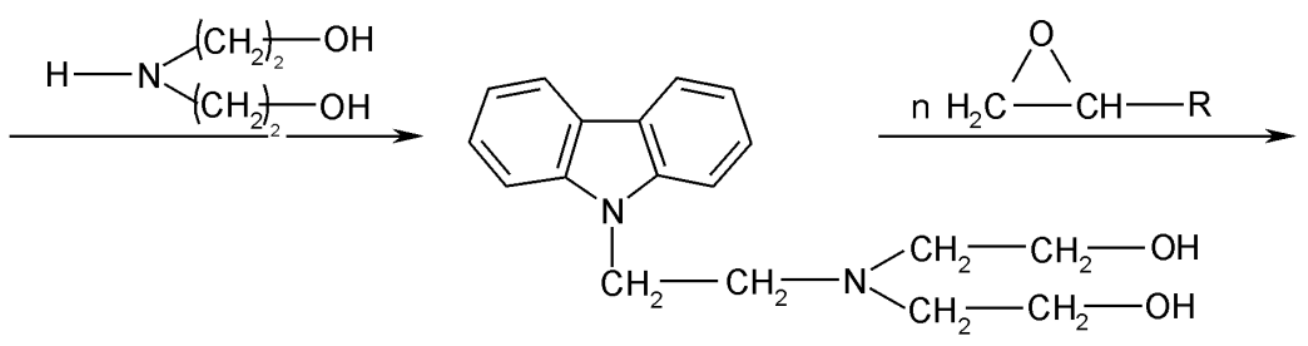<smiles>[R]C1CC(C)OCCOCCN(CCCn2c3ccccc3c3ccccc32)CCOC([R])C([R])OC([Y])O1</smiles>

The oligoetherols obtained in that way have similar properties like regular polyols used for obtaining polyurethanes. The reaction of those oligoetherols with bifunctional isocyanates led to linear polyurethanes of promising high thermal resistance [911]. Here the further results on multifunctional oligoetherols with carbazole ring, the convenient substrates to obtain polyurethane foams of enhanced thermal resistance are presented.

\section{Results and discussion}

\section{Synthesis of oligoetherols}

The reaction of carbazole with epichlorohydrin led to the formation of 9-(2,3-epoxypropyl) carbazole (EPC) according to the scheme (1), which underwent ring opening upon reaction with glycerol in presence of TEA to give three-functional 7-(9carbazolyl)-4-oxaheptane-1,2,6-triol (COHT,III) [12] according to the following reaction scheme: 

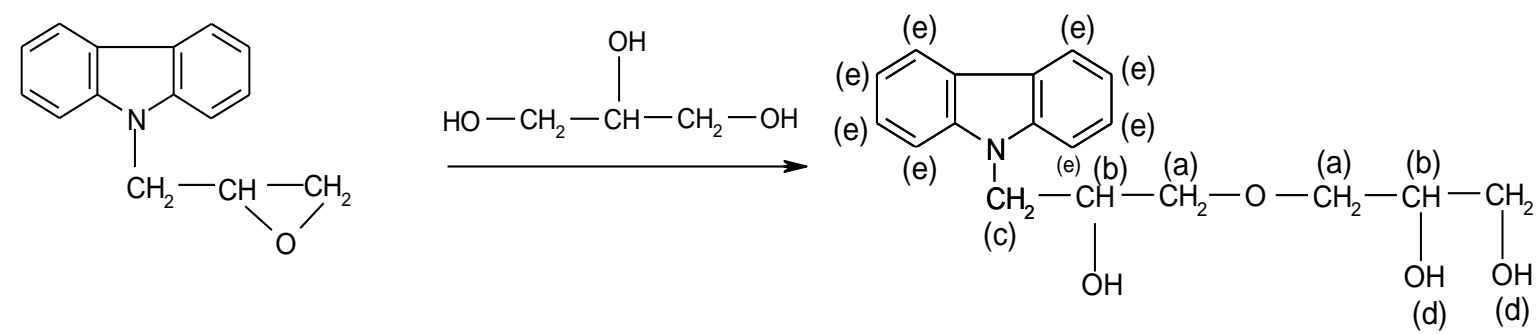

(III)

The process was performed without any solvent, using two equivalents of glycerol. The obtained COHT was semisolid resin, which was identified by elemental analytical, IR and ${ }^{1} \mathrm{H}$ NMR spectra (see Experimental; Analytical data of product). In the ${ }^{1} \mathrm{H}$ NMR spectrum the multiplet at $7.0-8.3 \mathrm{ppm}$ from carbazole ring protons was observed. The resonances of $-\mathrm{OH}$ were present with $4.8-5.1 \mathrm{ppm}$ region, the signals of methylene protons of $-\mathrm{CH}_{2} \mathrm{O}-$ were found at $3.2-3.7 \mathrm{ppm}$, while methine proton resonances were observed at $3.9-4.1 \mathrm{ppm}$. The aromatic $\mathrm{C}-\mathrm{H}$ bands were observed at 747 and $720 \mathrm{~cm}^{-1}$ in the IR spectra, the stretching $-\mathrm{OH}$ bands were found at $3350 \mathrm{~cm}^{-1}$ and $1152 \mathrm{~cm}^{-1}$, while valence bands of C-O-C were found at $1021 \mathrm{~cm}^{-1}$ and $1056 \mathrm{~cm}^{-1}$. The obtained product is readily soluble in oxiranes: EO and PO at room temperature. Addition of TEA to such a solution and heating the mixture to $60{ }^{\circ} \mathrm{C}$ triggered the reaction of formation of three-functional oligoetherols according to the scheme:<smiles></smiles>

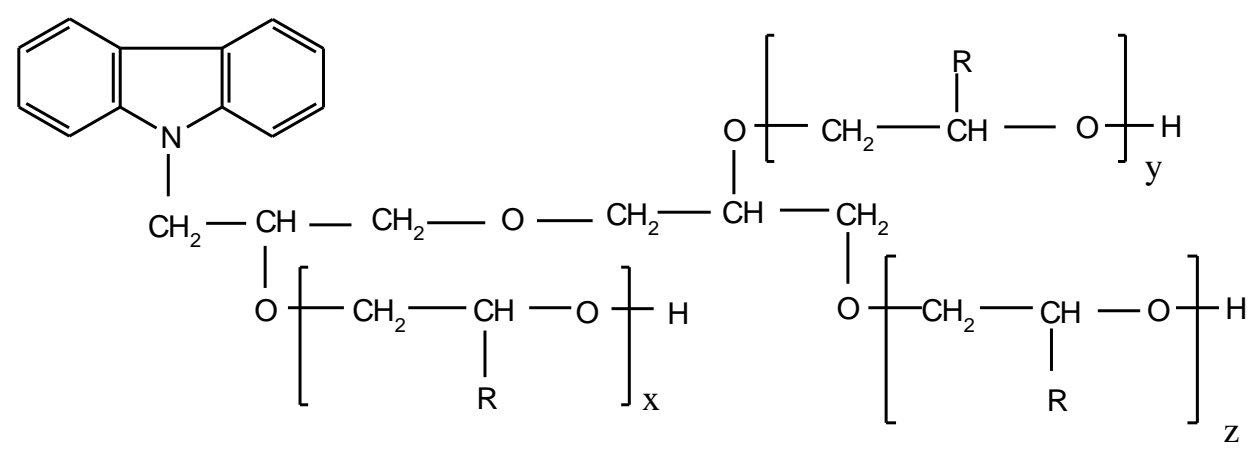

(IV)

where: $\mathrm{R}=-\mathrm{H},-\mathrm{CH}_{3}$

$$
\begin{aligned}
& x+y+z=n \\
& n-\text { number of molecules of attached oxirane }
\end{aligned}
$$

IR spectra of oligoetherols IV are remarkably different from that of COHT (III). The intensity of the band at $1050 \mathrm{~cm}^{-1}$ increased indicating formation of ether bonds (Fig.1) Also the band at $2900 \mathrm{~cm}^{-1}$ grew, indicating the incorporation of oxyalkylene units into oligoetherol. The intensity of the resonance at $3.5 \mathrm{ppm}$ in the ${ }^{1} \mathrm{H}-\mathrm{NMR}$ of oligoetherols IV (Fig.2) increased according to the increase of number of oxyalkylene 
units in a product. Simultaneously the resonances at $4.5-5.1 \mathrm{ppm}$ diminished illustrating the disappearance of hydroxyl protons due to progressing reaction of $\mathrm{OH}$ with oxirane. The structure of products of hydroxyalkylation of COHT was further confirmed by MALDI-TOF spectra (Table 1). The series of molecular peaks differing by $\mathrm{m} / \mathrm{z}=44$ or 58 , depending on used oxirane were characteristic for series of products, containing various amount of oxirane units.

The oligoetherols were obtained from the COHT: oxirane 1:6 molar ratio system. Some physical parameters like refraction index, density, viscosity and surface tension in function of temperature were studied (Fig. 3). Typical changes of those parameters in function of temperature were observed. The products obtained from EO had higher refraction index and density than those synthesized from PO. Generally the physical properties of oligoetherols synthesized here are similar to those of typical polyols used for obtaining polyurethane foams [13]. The synthesized oligoetherols have good thermal resistance (Table 2), especially these obtained from EO. Their thermal decomposition starts at $270-280^{\circ} \mathrm{C}$ (mass loss $5 \%$ ), while their temperature of $50 \%$ decomposition falls into $490-540{ }^{\circ} \mathrm{C}$ region. High thermal resis tance of these products suggested their usefulness as substrates for thermally resistant polyurethane foams.

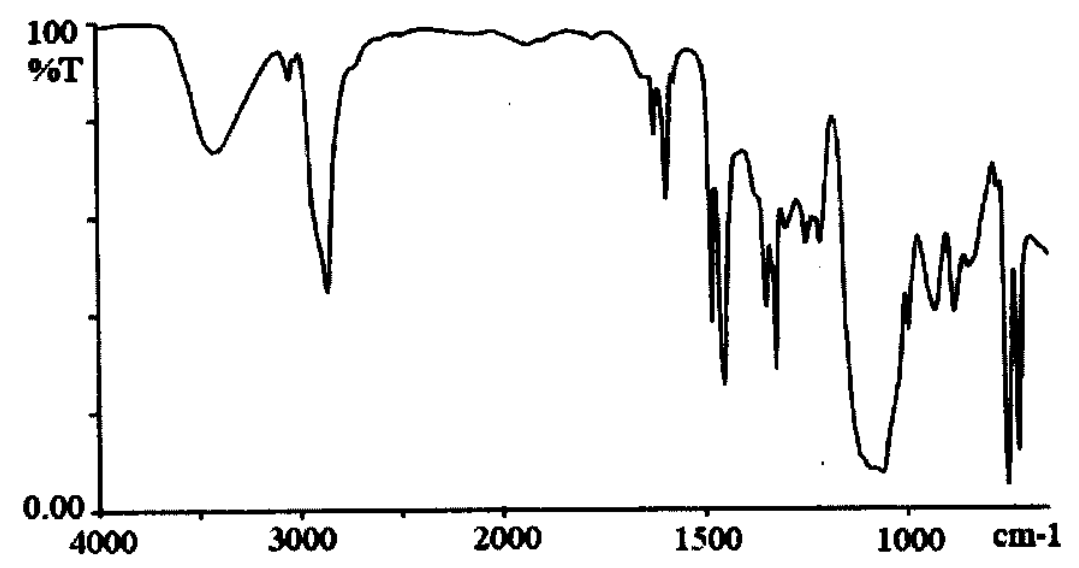

Fig. 1. IR spectrum of product of reaction of $\mathrm{COHT}$ with EO.

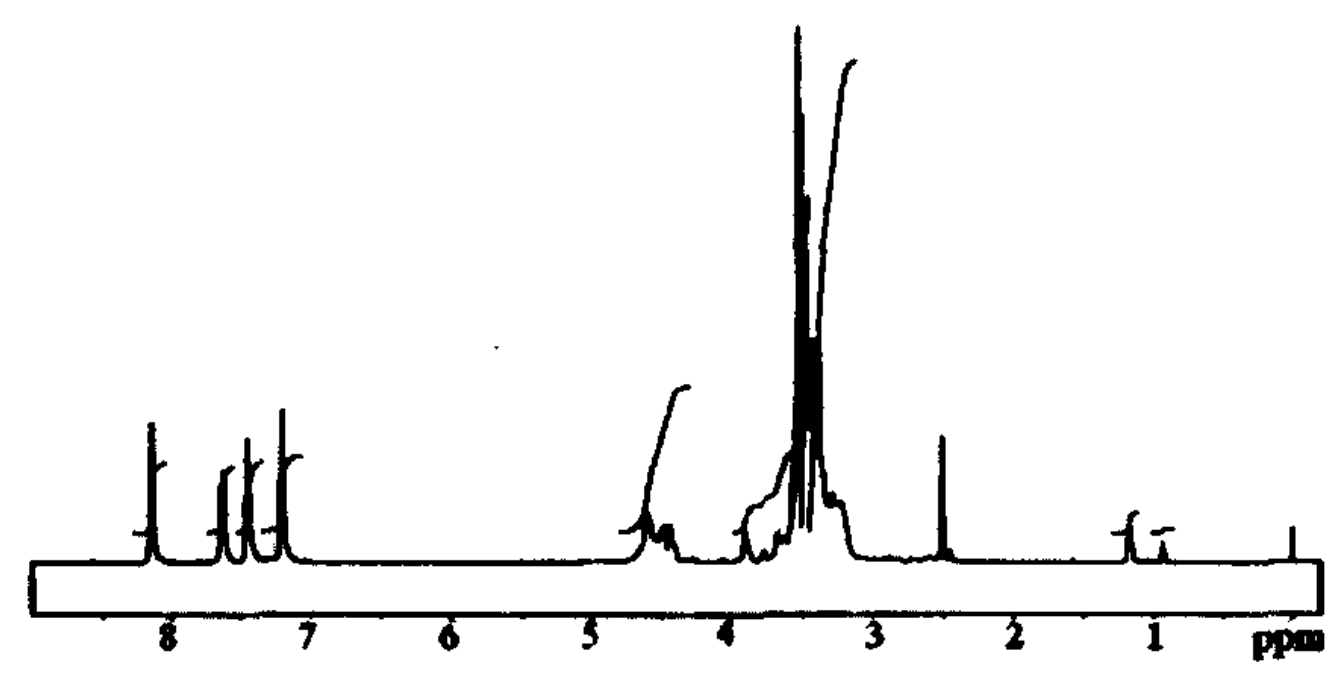

Fig. 2. H-NMR spectrum of product of reaction of $\mathrm{COHT}$ with EO. 
Tab. 1. Interpretation of MALDI ToF spectrum of reaction product obtained from 1 mole of $\mathrm{COHT}$ and 6 moles of $\mathrm{PO}$.

\begin{tabular}{cccc}
\hline $\begin{array}{c}\text { Signal } \\
\text { position } \\
\mathrm{m} / \mathrm{z}\end{array}$ & $\begin{array}{c}\text { Relative } \\
\text { intensity } \\
\text { of signal } \\
{[\%]}\end{array}$ & The molecular ion structure & $\begin{array}{c}\text { Calc. } \\
\text { molecular } \\
\text { weight } \\
\text { [g/mol] }\end{array}$ \\
\hline 276.3 & 84.7 & $\mathrm{EPC}+\mathrm{CH}_{3} \mathrm{OH}+\mathrm{Na}^{+}$ & 278 \\
334.4 & 100 & $\mathrm{COHT}+\mathrm{Na}^{+}$ & 336 \\
392.4 & 46.9 & $\mathrm{COHT}+\mathrm{PO}+\mathrm{Na}^{+}$ & 394 \\
450.4 & 10.2 & $\mathrm{COHT}+2 \mathrm{PO}+\mathrm{Na}^{+}$ & 452 \\
473.3 & 9.2 & $\mathrm{COHT}+3 \mathrm{PO}+\mathrm{Na}^{+}$ & 475 \\
531.3 & 3.1 & $\mathrm{COHT}+4 \mathrm{PO}+\mathrm{Na}^{+}$ & 533 \\
606.4 & 2.0 & $\mathrm{COHT}+5 \mathrm{PO}+\mathrm{H}^{+}$ & 606 \\
664.4 & 3.1 & $\mathrm{COHT}+6 \mathrm{PO}+\mathrm{H}^{+}$ & 664 \\
722.5 & 2.4 & $\mathrm{COHT}+7 \mathrm{PO}+\mathrm{H}^{+}$ & 722 \\
\hline
\end{tabular}

PO -oxyalkylene unit from propylene oxide

Tab. 2. Thermal stability of oligoetherols and polyurethane foams.

\begin{tabular}{ccccc}
\hline Product & $\begin{array}{c}\mathrm{T}_{5 \%} \\
{\left[{ }^{\circ} \mathrm{C}\right]}\end{array}$ & $\begin{array}{l}\mathrm{T}_{10 \%} \\
{\left[{ }^{\circ} \mathrm{C}\right]}\end{array}$ & $\begin{array}{l}\mathrm{T}_{25 \%} \\
{\left[{ }^{\circ} \mathrm{C}\right]}\end{array}$ & $\begin{array}{c}\mathrm{T}_{50 \%} \\
{\left[{ }^{\circ} \mathrm{C}\right]}\end{array}$ \\
\hline Oligoetherol COHT + EO & 280 & 300 & 380 & 540 \\
\hline $\begin{array}{c}\text { Foam obtained from } \\
\text { oligoetherol COHT + EO }\end{array}$ & 220 & 290 & 340 & 380 \\
\hline Oligoetherol COHT + PO & 270 & 280 & 330 & 490 \\
\hline $\begin{array}{c}\text { Foam obtained from } \\
\text { oligoetherol COHT + PO }\end{array}$ & 190 & 240 & 310 & 360 \\
\hline
\end{tabular}

\section{Studies of foams}

The polyurethane foams were performed on laboratory scale (Table 3). The optimization of amount of isocyanate, foaming agent (amount of water), catalyst and kind of oligoetherol was performed for foaming. The water amount was optimized for the oligoetherol obtained from EO as $2 \%$ water related to mass of oligoetherol; the use of higher water percentage led to the formation of irregular pores. The amount of catalyst was also crucial; the rigid foams were obtained when $1.25 \%$ catalyst was applied in case of oligoetherol obtained from EO was used and $3.34 \%$ in case of oligoetherol obtained from PO.

The best foams were obtained when the molar ratio of 4,4'-diphenylmethane diisocyanate to number of hydroxyl groups was maintained at the level of 1.6 for the oligoetherol obtained from EO and 1.4 in case of the oligoetherol synthesized from PO. Lower or higher ratio led to underhardened foams with large pores.

Foaming compositions showed short creaming times (8 sec.) and grow times (to 30 sec.). Drying times in case of compositions from EO was $3 \mathrm{~s}$, while in case of PO it was as long as 90 seconds. 

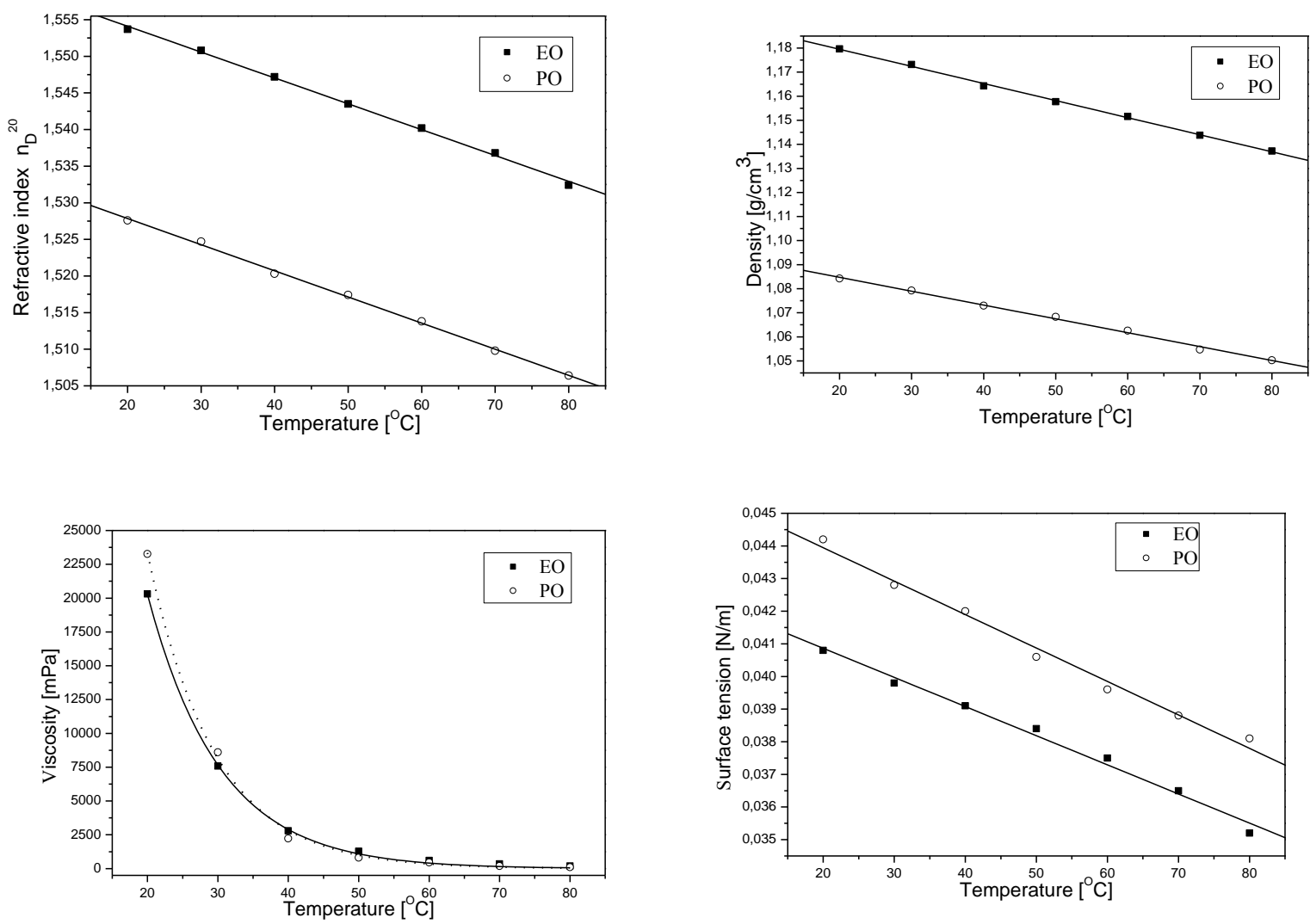

Fig. 3. Physical properties of oligoetherols obtained in reaction of COHT with oxiranes versus temperature.

The best foams, the rigid ones and with unisized pores were subjected to density, size stability at $150^{\circ} \mathrm{C}$, water uptake, thermal resistance and change of mechanical properties upon thermal exposure (Table 4). It has been found that the obtained foams are rigid at room temperature and their apparent density was $40-44 \mathrm{~kg} / \mathrm{m}^{3}$. The water uptake was low, maximum to 6.5 mass $\%$. The dimensional stability at 150 ${ }^{\circ} \mathrm{C}$ measurements revealed that the dimension change was no larger than $5 \%$ of initial dimension.

Dynamic thermal analysis showed that $5 \%$ mass loss starts at ca. $200{ }^{\circ} \mathrm{C}$, while temperature of $50 \%$ mass loss was $360-380{ }^{\circ} \mathrm{C}$ (Table 2). Long-lasting, static measurements of thermal resistance were conducted at $150{ }^{\circ} \mathrm{C}$ for one month (Fig. 4). Continuous decrease of foam mass was observed throughout the test, however the largest mass loss was noticed at the first day of heating. The mass loss of foam obtained from oligoetherol synthesized from COHT and EO was 11,5 mass \% within one month. Concomitantly the increase of compression strength was observed, for instance the foams obtained from oligoetherol synthesized with $\mathrm{EO}$ showed twice increase of compression strength after one month heating at $150{ }^{\circ} \mathrm{C}$, presumably due to extended crosslinking upon thermal exposition. Thermal stability of obtained foams was compared with thermal stability of a typical, industrial, rigid polyurethane foam (Table 4). It is said that mass loss in 150 degree after 14 days is significant and reaches almost $50 \%$.At the same time, these conditions cause deformation of foams and they are no more suitable for tests of strength. 
Tab. 3. The influence of composition of foaming process.

\begin{tabular}{|c|c|c|c|c|c|c|c|c|c|}
\hline \multirow{2}{*}{$\begin{array}{l}\text { Oligoetherol } \\
\text { obtained } \\
\text { with the use } \\
\text { of }\end{array}$} & \multirow{2}{*}{$\begin{array}{l}\text { Compo- } \\
\text { siton } \\
\text { number }\end{array}$} & \multicolumn{3}{|c|}{$\begin{array}{l}\text { Composition* } \\
\text { g/100g of } \\
\text { oligoetherol }\end{array}$} & \multirow{2}{*}{$\begin{array}{c}\text { Molar } \\
\text { ration } \\
\text { OH:NCO } \\
\text { (isocy- } \\
\text { anate } \\
\text { coeffi- } \\
\text { cient }\end{array}$} & \multicolumn{3}{|c|}{ Foaming process } & \multirow[t]{2}{*}{$\begin{array}{l}\text { Characteristics } \\
\text { of foams just } \\
\text { prepared }\end{array}$} \\
\hline & & $\begin{array}{c}\text { izocya- } \\
\text { nate }\end{array}$ & TEA & $\begin{array}{l}\text { wa- } \\
\text { ter }\end{array}$ & & $\begin{array}{l}\text { Time of } \\
\text { creaming } \\
\text { [s] }\end{array}$ & $\begin{array}{c}\text { Time } \\
\text { of } \\
\text { expan- } \\
\text { ding } \\
\text { [s] }\end{array}$ & $\begin{array}{c}\text { Time } \\
\text { of } \\
\text { drying } \\
{[s]}\end{array}$ & \\
\hline \multirow{7}{*}{ EO } & 1 & 116 & 1.25 & 2 & 1.57 & $15 \pm 1$ & $28 \pm 2$ & $2 \pm 0.5$ & underhardened \\
\hline & 2 & 144 & 2.08 & 2 & 2.00 & $12 \pm 1$ & $14 \pm 1$ & $5 \pm 1$ & large pores \\
\hline & 3 & 132 & 2.92 & 3 & 1.82 & - & - & - & $\begin{array}{l}\text { irregular pore } \\
\text { sizes }\end{array}$ \\
\hline & 4 & 240 & 3.75 & 4 & 3.48 & $6 \pm 1$ & $10 \pm 1$ & $2 \pm 0.5$ & large pores \\
\hline & 5 & 116 & 1.67 & 2 & 1.57 & 10 & $14 \pm 2$ & $2 \pm 0.5$ & large pores \\
\hline & 6 & 116 & 1.25 & 2 & 1.57 & $8 \pm 1$ & $17 \pm 2$ & $3 \pm 0.5$ & rigid \\
\hline & 7 & 116 & 1.25 & 2 & 1.57 & $8 \pm 1$ & $23 \pm 2$ & $3 \pm 0.5$ & rigid \\
\hline \multirow{5}{*}{$\mathrm{PO}$} & 8 & 104 & 2.50 & 2 & 1.39 & $8 \pm 1$ & $42 \pm 3$ & $90 \pm 5$ & fragile \\
\hline & 9 & 104 & 3.34 & 2 & 1.39 & $8 \pm 1$ & $28 \pm 2$ & $97 \pm 5$ & rigid \\
\hline & 10 & 104 & 3.75 & 2 & 1.39 & $5 \pm 1$ & $30 \pm 2$ & $90 \pm 5$ & underhardened \\
\hline & 11 & 104 & 4.17 & 2 & 1.39 & $8 \pm 1$ & $30 \pm 2$ & $90 \pm 5$ & underhardened \\
\hline & 12 & 104 & 3.34 & 2 & 1.39 & $6 \pm 1$ & $32 \pm 2$ & $90 \pm 5$ & riqid \\
\hline
\end{tabular}

* Amount of surfactant $2 \mathrm{~g}$ per $100 \mathrm{~g}$ of oligoetherols

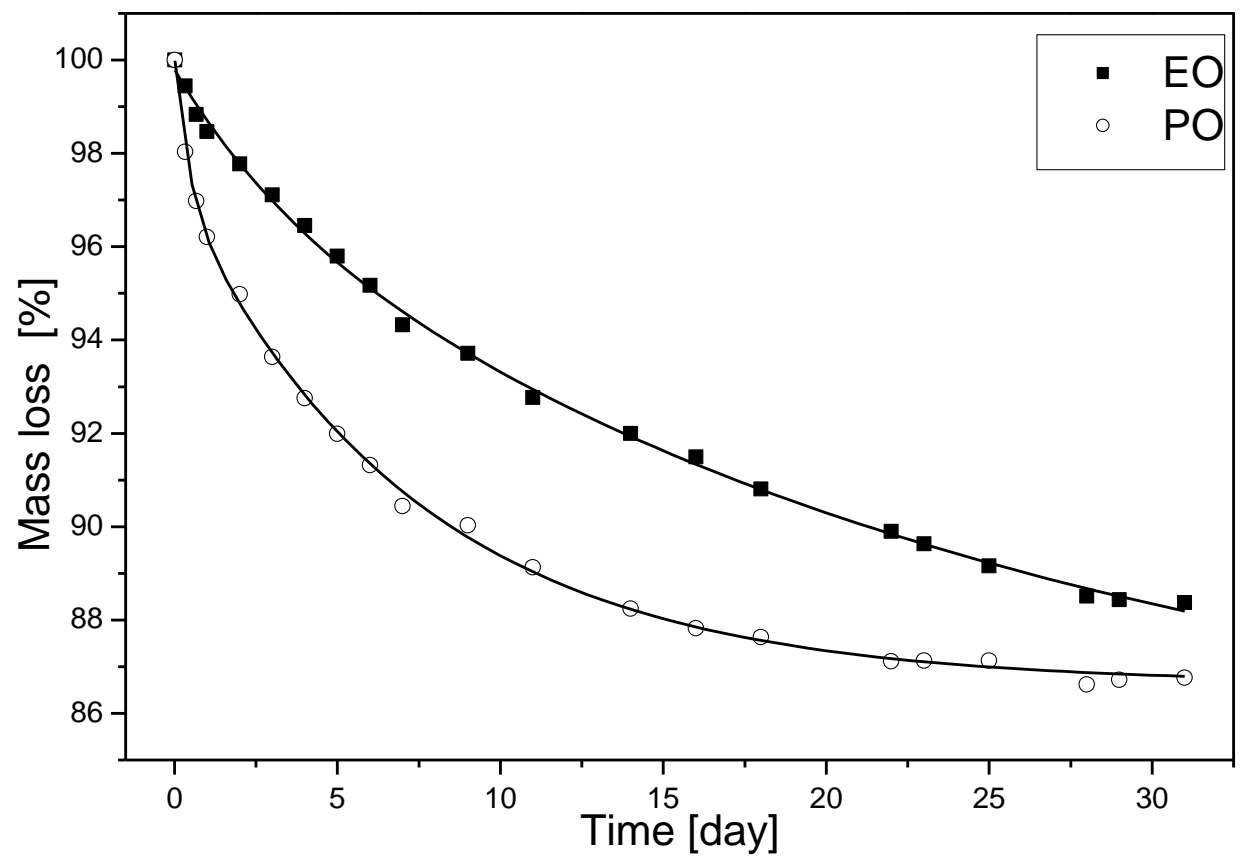

Fig. 4. Thermal stability of polyurethane foams as the weight loss after heating at 150 ${ }^{\circ} \mathrm{C}$ for a month. 
Tab. 4. Some properties of polyurethane foams.

\begin{tabular}{|c|c|c|c|c|c|c|c|c|c|c|}
\hline \multirow{2}{*}{$\begin{array}{l}\text { Polyurethane } \\
\text { foams }\end{array}$} & \multirow{2}{*}{$\begin{array}{l}\text { Density } \\
{\left[\mathrm{kg} / \mathrm{m}^{3}\right]}\end{array}$} & \multicolumn{3}{|c|}{$\begin{array}{l}\text { Water uptake } \\
{[\%] \text { after }}\end{array}$} & \multicolumn{3}{|c|}{$\begin{array}{c}\text { Linear dimension stability } \\
\text { [\%] at temperature } 150^{\circ} \mathrm{C} \\
\text { after } 40 \mathrm{~h}\end{array}$} & \multirow{2}{*}{$\begin{array}{c}\text { Mass loss in } \\
\text { temp. } \\
150^{\circ} \mathrm{C} \text { after } \\
14 \text { day [\%] }\end{array}$} & \multicolumn{2}{|c|}{$\begin{array}{c}\text { Compression Strength } \\
{[\mathrm{MPa}]}\end{array}$} \\
\hline & & $5 \mathrm{~min}$. & $3 \mathrm{~h}$ & $24 \mathrm{~h}$ & $\begin{array}{l}\text { Length } \\
\text { change }\end{array}$ & $\begin{array}{l}\text { width } \\
\text { change }\end{array}$ & $\begin{array}{l}\text { depth } \\
\text { change }\end{array}$ & & $\begin{array}{l}\text { before } \\
\text { exposition }\end{array}$ & $\begin{array}{l}\text { after exposition by } \\
\text { month in } \\
\text { temperature } 150^{\circ} \mathrm{C}\end{array}$ \\
\hline $\begin{array}{l}\text { obtained from } \\
\text { oligoetherol } \\
\text { on EO } \\
\text { obtained from }\end{array}$ & $\begin{array}{c}44.0 \pm 3 . \\
1\end{array}$ & $\begin{array}{c}2.25 \pm \\
0.10\end{array}$ & $\begin{array}{c}4.33 \pm \\
0.12\end{array}$ & $\begin{array}{l}6.52 \pm \\
0.25\end{array}$ & $\begin{array}{l}5.14 \pm 0 . \\
\quad 05\end{array}$ & $\begin{array}{c}4.58 \pm 0 \\
10\end{array}$ & $\begin{array}{l}0.51 \pm 0 . \\
01\end{array}$ & 7.77 & $\begin{array}{l}0.172 \pm 0.0 \\
05\end{array}$ & $0.324 \pm 0.006$ \\
\hline $\begin{array}{l}\text { oligoetherol } \\
\text { on PO }\end{array}$ & $\begin{array}{l}40.0 \pm 5 \\
0\end{array}$ & $\begin{array}{c}1.79 \pm \\
0.08\end{array}$ & $\begin{array}{c}3.75 \pm \\
0.10\end{array}$ & $\begin{array}{c}6.54 \pm \\
0.34\end{array}$ & $\begin{array}{c}2.16 \pm 0 \\
06\end{array}$ & $\begin{array}{c}0.14 \pm 0 \\
01\end{array}$ & $\begin{array}{c}1.54 \pm 0 . \\
12\end{array}$ & 11.36 & $\begin{array}{c}0.324 \pm 0.0 \\
08\end{array}$ & $0.394 \pm 0.004$ \\
\hline $\begin{array}{l}\text { classical } \\
\text { industrial }\end{array}$ & $\begin{array}{l}26.0 \pm 3 . \\
2\end{array}$ & $\begin{array}{l}2.13 \pm \\
0.07\end{array}$ & $\begin{array}{l}4.05 \pm \\
0.13\end{array}$ & $\begin{array}{c}5.52 \pm \\
0.28\end{array}$ & * & * & * & 49.14 & * & * \\
\hline
\end{tabular}

\section{Conclusions}

Three-functional oligoetherols with carbazole ring can be obtained starting from carbazole, by consecutive conversions with epichlorohydrin to 9-(2,3epoxypropyl)carbazole, ring opening with glycerol, and finally by reaction with oxiranes $\mathrm{EO}$ or $\mathrm{PO}$. The oligoetherols have similar properties as those used regularly for obtaining polyurethane foams except higher thermal resistance of the former. Obtained oligoetherols are useful substrates for synthesis of polyurethane foams which have enhanced thermal resistance and remain unchanged upon long exposure at $150{ }^{\circ} \mathrm{C}$.

\section{Experimental}

\section{Synthesis}

The synthesis of 9-(2,3-epoxypropyl)carbazole (EPC) was performed as previously reported [12].

\section{Opening of epoxide ring with glycerol}

To a $100 \mathrm{~cm}^{3}$ three-necked round bottom flask equipped with reflux condenser, mechanical stirrer and thermometer $25.0 \mathrm{~g}(0.11 \mathrm{~mole})$ of EPC and $11.8 \mathrm{~cm}^{3}(0.16$ mole) of glycerol (pure, $\mathrm{POCH}$, Gliwice, Poland) were introduced. The mixture was stirred and heated until dissolving of substrated (at temperature ca. $60{ }^{\circ} \mathrm{C}$ ), then $0.1 \mathrm{~cm}^{3}$ triethylamine (TEA, pure, Fluka, Buchs, Switzerland) catalyst was added. The mixture was heated to $120{ }^{\circ} \mathrm{C}$. The progress of reaction was monitored by determination of epoxide number (EN). Then $50 \mathrm{~cm}^{3}$ distilled water was added, the mixture was vigorously stirred and heated at $90{ }^{\circ} \mathrm{C}$ for about one hour to rinse the glycerin off. The mixture was cooled down to room temperature and water layer was removed, washed couple of limes with water and final product: (COHT, III) as dense brown resin was vacuum dried at $80^{\circ} \mathrm{C}$ to remove water.

Analytical data of COHT (III): Yield - 65\%; elemental analysis - \% Calcd.: C 68.55\%; N 4.44\%; H 6.71\%; \% Found: C 68.22\%; N 4.52\%; H 6.73\%; IR (HATR) [cm ${ }^{-1}$ ], 3350 (O-H), 3048 (Ar-H), $2858-2926\left(\mathrm{CH}_{2}, \mathrm{CH}\right), 1626,1595(\mathrm{C}=\mathrm{C}), 1451\left(\mathrm{CH}_{2}\right), 1324$ (C$\mathrm{N}), 1212,1152$ (C-O), 1021, 1056 (C-O-C), 747, 720 (C-H in ring); ${ }^{1} \mathrm{H}-\mathrm{NMR}\left(\mathrm{d}_{6^{-}}\right.$ 
DMSO), [ppm] a $3.2-3.7(\mathrm{~m})$; b $3.8-4.1(\mathrm{~m})$; c $4.2-4.6(\mathrm{~m})$; d $4.8-5.1(\mathrm{~m})$, e $7.0-$ $8.3(\mathrm{~m})$.

\section{Reaction of COHT with oxiranes}

In a pressure reactor of $250 \mathrm{~cm}^{3}$ volume equipped with magnetic stirrer and thermometer $25.0 \mathrm{~g}(0.08$ mole $)$ of COHT, $1 \mathrm{~cm}^{3}$ (0.007 mole) catalyst (TEA) and $21.0 \mathrm{~g}$ ( 0.48 mole) EO or $27.6 \mathrm{~g}$ ( 0.48 mole) PO were placed. The mixture was stirred and heated to $60-90{ }^{\circ} \mathrm{C}$. The progress of reaction was monitored by determination of EN. The products were brown resins, from which the catalyst was removed by distillation under reduced pressure ( $p=2132 \mathrm{~Pa}$, temp. $80^{\circ} \mathrm{C}$ ).

Analytical data of oligoetherols (IV):

$\mathrm{R}=-\mathrm{H}$ : IR (HATR) $\left[\mathrm{cm}^{3}\right]: 3424(\mathrm{OH}), 3050(\mathrm{Ar}-\mathrm{H}), 2986-2912\left(\mathrm{CH}_{2}, \mathrm{CH}\right), 1626$, 1624, $1597(\mathrm{C}=\mathrm{C}), 1484,1452\left(\mathrm{CH}_{2}\right), 1325(\mathrm{C}-\mathrm{N}), 1215$ (C-O in alcohols), 10641113 (C-O-C), 747, 720 (Ar-H), (Fig.1); ${ }^{1} \mathrm{H}-\mathrm{NMR}$ (DMSO-d 6 ) [ppm]:7.0-8.1(Ar- H); 4.5 $(-\mathrm{OH}) ; 4.3\left(>\mathrm{N}-\mathrm{CH}_{2}-\right) ; 3.9(\mathrm{C}-\mathrm{H}) ; 3.2-3.7\left(\mathrm{CH}_{2}-\mathrm{O}-\right)$ (Fig.2).

$\mathrm{R}=-\mathrm{CH}_{3}:$ IR (HATR) $\left[\mathrm{cm}^{3}\right]: 3428(\mathrm{OH}), 3054(\mathrm{Ar}-\mathrm{H}), 2969-2870\left(\mathrm{CH}_{2}, \mathrm{CH}\right)$, 1626,1597 ( $\mathrm{C}=\mathrm{C}), 1484,1453\left(\mathrm{CH}_{3}\right), 1373(\mathrm{C}-\mathrm{N}), 1215,1152$ (C-O in alcohols), 10841113(C-O-C), 758, 730 (Ar-H); ${ }^{1} \mathrm{H}-\mathrm{NMR}$ (DMSO-d $\mathrm{d}_{6}$ [ppm]: $7.0-8.1$ (Ar- H); $4.5-4.3$ $\left(-\mathrm{OH}\right.$ and $\left.>\mathrm{N}-\mathrm{CH}_{2}-\right)$; 3.7- $3.9(-\mathrm{CH})$; 3.2- 3.7 $\left(\mathrm{CH}_{2}-\mathrm{O}-, \mathrm{CH}-\mathrm{O}-\right)$; $0.7-1.2\left(\mathrm{CH}_{3}\right)$.

\section{Analytical determinations}

The course of reaction between carbazole and epichlorohydrin, EPC and glycerol and between $\mathrm{COHT}$ and oxiranes was followed by measuring the content of unreacted epoxide groups by hydrochloric acid method in dioxane [13]. Elemental analysis for $\mathrm{C}, \mathrm{H}, \mathrm{N}$, were done with $\mathrm{EA} 1108$, Carlo-Erba analyzer. The ${ }^{1} \mathrm{H}-\mathrm{NMR}$ spectra of products were recorded at $500 \mathrm{MHz}$ Bruker UltraShield in DMSO-d 6 with hexamethyldisiloxane as internal standard. IR spectra were registered on PARAGON 1000 FT IR Perkin Elmer spectrometer in KBr pellets or ATR technique. MALDI ToF (Matrix-Assiated Laser Desorption Ionization Time of Flight) of oligoetherols were obtained on Voyager-Elite Perseptive Biosystems (USA) mass spectrometer working at linear mode with delayed ion extraction, equipped with nitrogen laser working at $337 \mathrm{~nm}$. The method of laser desorption from matrix was used with 2,5hydroxybenzoic acid in THF at $\mathrm{mg} / \mathrm{cm}^{3}$ concentration. The samples with diluted with methanol to $1 \mathrm{mg} / \mathrm{cm}^{3}$, followed by addition of $10 \mathrm{mg} / \mathrm{cm}^{3} \mathrm{Nal}$ in acetone. Therefore in some cases the molecular ion masses were increased by the mass of $\mathrm{Na}^{+}$and $\mathrm{CH}_{3} \mathrm{OH}$. Thermal analyses of oligoetherols and foams (DTA, DTG and TG) were performed in ceramic crucible at $20-600{ }^{\circ} \mathrm{C}$ temperature range, about $200 \mathrm{mg}$ sample, under air atmosphere with Termowaga TGA/DSC 1 derivatograph, Mettler.

\section{Physical properties of oligoetherols}

Refraction index, density, viscosity, and surface tension of oligoetherols were determined with Abbe refractometer, picnometer, Höppler viscometer (typ BHZ, prod. Prüfgeratewerk, Germany) and by the detaching ring method, respectively.

\section{Foam Preparation}

Foaming tests were conducted on laboratory scale in $250 \mathrm{~cm}^{3}$ paper cups at room temperature. In details oligoetherol $(10 \mathrm{~g})$ was mixed with $0.2 \mathrm{~g}$ of Silicone 5340 
(pure, Houdry Hülls, USA) as surfactant, TEA as catalyst (1-3 wt \%) and water (2\% wt \%) with respect to oligoetherols. A calculated portion of diphenylmethane 4,4diisocyanate (commercial isocyanate containing three-functional isocyanates at the level of 30\%; MDI, pure, Merck, Darmstadt, Germany, was used) was then added and the mixture was vigorously stirred until the contents were creamed. Test samples were cut out from the foams thus obtained.

\section{Studies of foams}

The following properties of foams were studied: apparent density [15], water uptake [16], linear shrinkage estimated on the basis of the change of linear dimension of the sample heated for 4 hours at $100{ }^{\circ} \mathrm{C}$ [17], thermal stability as the weight loss at 150 ${ }^{\circ} \mathrm{C}$ within one month and compression strength [18].

\section{References}

[1] Jpn Pat. 1989, 01311161; Chem. Abst. 1990, 81, 144251c.

[2] Ke, X. J.; Yan, X. Z.; Srisanit, N.; Wang, M.; Yang, J.W.; Huang, X., F.; Shong, S.

Z. Appl. Phys., 2003, 217, 69.

[3] Gratt, J. A.; Cohen, R.E. J. Appl. Polym. Sci., 2003, 88, 177.

[4] Zhu, W. H.; Hu, M.; Rao, R.; Tian, H. J. Photochem. Photobiol. A-Chem., 2003, 154,169 .

[5] Lee, J., H.; Woo, H., S.; Kim, T.W.; Park, J. W. Optical Mat., 2003, 21, 225.

[6] Zhang, X.J.; Thian, Y.P.; Jiang, S.L.M. Polyhedron, 2003, 22, 397.

[7] Tirapattur, S.; Belletete, M.; Drolet, N.; Leclerc, N.; Durocher, G. Chem. Phys. Lett., 2003, 370, 799.

[8] Joule, J. A. Adv. Heterocyclic Chem., 1984, 35, 83.

[9] Lubczak, R. Polimery, 2008, 53, 587.

[10] Lubczak, R. J. Appl. Pol. Sci.; 2008, 110, 3501.

[11] Lubczak, R. J. Appl. Pol. Sci.; 2010, 117, 16.

[12] Lubczak, R. Heterocycl. Comm.; 2006, 12, 201.

[13] Wirpsza Z. Polyurethane, WNT, Warsaw 1991 ( in polish).

[14] Kastierina, T.; Kalinina, L. Chemical analysis of plastics Ed. WNT, Warsaw 1965 (in Polish).

[15] Cellular Plastics and Rubbers. Determination of apparent (bulk) Density, Polish (European) Standards PN-EN ISO 845-2000, Ed. Polish Committee for Standardization.

[16] Cellular Plastics, rigid. Determination of Water Absorption, Polish (European) Standards PN-EN ISO 2896-1986, Ed. Polish Committee for Standardization.

[17] Cellular Plastics, rigid. Test of dimensional Stability, Polish (European) Standards PN-EN ISO 2796-1986, Ed. Polish Committee for Standardization.

[18] Cellular Plastics, Compression Test for rigid Materials, Polish (European) Standards PN- EN ISO 844-1978, Ed. Polish Committee for Standardization. 